\title{
Jonas Čičinskas*
}

Vilniaus universiteto Tarptautiniu santykiu ir politikos mokslu institutas

Arūnas Dulkys

Vilniaus universiteto Ekonomikos fakultetas

\section{Finansų krizè ir nauji sprendimai Europos Sajungoje: mažos valstybès atvejis}

\begin{abstract}
Straipsnyje nagrinėjamos galimos Lietuvos ekonominės strategijos slinktys, ịvykus 2008-2009 metų krizei (Didžiajai recesijai) ir kintant makroekonominei aplinkai Europos Sajungoje (ES). Lietuvos, kaip ir kitų dviejų Baltijos valstybių, atveju išryškèjo tam tikra mažųjų atviros ekonomikos valstybių padèties specifika ir strategijos modifikavimo poreikis. Tiek sparti Baltijos valstybių ekonominė pažanga, tiek itin didelis jų ūkio nusmukdymas krizès metu didžiausia dalimi buvo tų mažųjų nacionalinių ekonomikų integracijos ¡̇ Europos ir pasaulio rinkas padarinys. Krizè ne tik keleriems metams sustabdė ES ir kitų pasaulio šalių ekonominę pažangą, ne tik paskatino peržiūrèti kai kuriuos susvyravusius ekonomikos teorijos postulatus, bet ir pareikalavo imtis esminių korekcijų valstybių ir ES ekonomineje politikoje. Pagal Europos komisijos pateiktus projektus jau susitarta dèl griežtesnių Stabilumo ir augimo pakto reikalavimų, pasirašyta ir ratifikuota Sutartis dèl stabilumo, koordinavimo ir valdysenos ekonominèje ir pinigų sąjungoje, èmè veikti Europos semestro procedūros. ES šalių narių ekonominè politika jau įsprausta į griežtesnius rèmus, šis procesas nacionalinių ekonominès politikos turinio subendrinimo link tęsis ir toliau. Pasiremiant teoriniais optimalios valiutos erdvès ir praktiniais bendrosios pinigų politikos reikalavimais euro erdvëje integraciniai procesai vyksta ir vyks ypač sparčiai. Europos vadovų tarybos sprendimu euro erdvè turi tapti ES valstybių ekonominès integracijos branduoliu, vedančiu uniją iki visiškos ekonominės sajungos. ES politiniai lyderiai, remdamiesi valstybių Europos integracijos teorijomis, jau kelia ị darbotvarkę ir politinès sąjungos klausimą. Straipsnyje teikiama šių pokyčiu analizè ir iškeliama keletas tezių. Pirma, ekonominès integracijos procesą būtina griežčiau nei iki šiol skirti nuo politinès integracijos proceso. Antra, ekonominè integracija modifikuoja valstybių suverenumą (vis labiau pereinama prie unifikuotų ekonominès politikos principų ir ekonominių sprendimų apibendrinimo), kuri neturi būti tapatinama su dalies suverenumo praradimu, tačiau reikalauja naujai vertinti nacionalinès ekonominès politikos modifikavimo veiksnius ir motyvus ir jos vaidmenį užtikrinant šalies suverenumą. Trečia, mažųjų valstybių ekonominè strategija ir toliau turi remtis aktyviu Europos ekonominiu integravimusi, šiame procese pirmenybę teikiant realiajai ekonominei konvergencijai (ekonominio atsilikimo likvidavimui) ir realiam dalyvavimui darant sprendimus integruotos ES ekonomikos klausimais. Daroma išvada, kad tokių nuostatų pagrindu būtų įmanoma atskirti nenumaldomą, racionalumo principu pagrịstą ES ekonominès integracijos procesą nuo Europos valstybių politinès unijos tariamo liepimo.
\end{abstract}

\footnotetext{
" Prof., habil. dr. Jonas Čičinskas yra Vilniaus universiteto Tarptautinių santykių ir politikos mokslų instituto profesorius. Adresas korespondencijai: Vokiečių g. 10, 01130 Vilnius,

el. p. jonas.cicinskas@tspmi.vu.lt

${ }^{* *}$ Dr. Arūnas Dulkys yra Vilniaus universiteto Ekonomikos fakulteto Teorinès ekonomikos katedros lektorius. Adresas korespondencijai: Sauletekio 9-2-511, 10222 Vilnius, tel. (8 5)236 6147,

el. p. arunas.dulkys@vkontrole.lt, arunas.dulkys@gmail.com
} 


\section{Ivadas}

Spartejanti technologijų pažanga ir sklaida ne tik igalino pasaulio nacionalines ekonomikas didinti produktyvumą ir kelti gerovę, bet ir pastūmèjo vis intensyvesnių ekonominių mainų link ir jų sąlygotos didejančios tarpusavio priklausomybès. Politikų darbotvarkèse ir mokslininkų tyrimų projektuose tarptautinio bendradarbiavimo, globalizacijos ir regioninès integracijos problemos neišvengiamai užima vis svarbesnę vietą.

Šie pokyčiai anaiptol ne vien nominalūs. Jie palaipsniui transformuoja nacionalines ekonomikas ị regioninius ir pasaulinius ekonominius kompleksus, susaistytus prekybos ir kapitalo srautais ir kooperatiniais gamybos tinklais. Kontinentiniai ekonomikos kompleksai negailestingai ardo santykinị nacionalinių ekonomikų autonomiškumą, tuo neigdami tradiciškai suprantamą valstybių ekonominị suverenumą ir reikalaudami naujo požiūrio ị nacionalinę ekonominę politiką. Dabartinė praktiškai tebesitęsianti krizè - ne visame pasaulyje, o labiausiai išsivysčiusioje jo dalyje - ịrodo, kad lig šiol naudotas ekonominès politikos priemonių arsenalas turi būti atnaujintas, o to atnaujinimo kryptis - didesnis orientavimasis ị išorés ekonomikos veiksnius ir tarptautini bendradarbiavimą valstybių ekonominèje politikoje. Kai kurie analitikai netgi siūlo permąstyti ir esminius ekonomikos teorijos klausimus.

Intelektinis dviejų stovyklų ekonomistų ginčas ir JAV ir Europos Sajungos (ES) politikų priešstata, renkantis išèjimo iš krizès kelią, ypač aktualus mažoms atviros ekonomikos valstybėms. Priežastis čia ta, kad dvi alternatyvios strategijos spręsti krizès sukeltą ükio depresiją pateikiamos kaip lygiavertès, o faktiškai tokiomis jos tèra tik didelèms nacionalinèms ekonomikoms, kurių priklausomybè nuo išorès prekių ir kapitalo rinkų yra mažesnè nei mažųjų nacionalinių ekonomikų. Tariamas tų strategijų - paklausos skatinimo deficitiniu finansavimu, tikintis paskesnio viešųų finansų subalansavimo atsigaunant ekonomikai, ir viešųju finansų deficito eliminavimo, tikintis investicijų suaktyvejjimo - lygiavertiškumas mažosioms valstybėms gresia nepalyginamai didesniu nacionalinio ūkio destabilizavimu nei didžiosioms, nes pasirinkusios pirmają strategiją jos sulauktų kur kas galingesnio infliacijos impulso nei didžiosios valstybès ir būtų ịtrauktos ị ilgam ūkị destabilizuojančią infliacijos spiralę.

Taigi, dabartinė finansų ir ekonomikos krizè reikalauja iš naujo pažvelgti į mažųjų valstybių ekonominès politikos specifiką. Jos analizè leis pasiūlyti ir naujų ižvalgų tolesnei diskusijai apie tai, kokia ekonominè strategija rekomenduotina mažoms nacionalinėms ekonomikoms vykstant sparčiai regioninei ir pasaulinei ekonominei integracijai. 
Principinès ekonominès politikos nuostatos reikalauja užtikrinti valstybès ekonominị saugumą. Ekonominis saugumas tiesiogiai siejamas su ekonomine nepriklausomybe (suverenumu). Kiekviena valstybė susisaisto, siekdama sau saugumo ir naudos, gausẻjančiais tarptautiniais ịsipareigojimais, tarp jų - ir ịsipareigojimais ekonominès politikos srityje (stojant ị tokias tarpvalstybines organizacijas, kaip PPO, TVF, PB, TDO, pasirašant daugiašales ir dvišales prekybos, investicijų apsaugos ir pan. sutartis su kitomis valstybėmis). Toks susisaistymas stiprès ir toliau. Pakanka paminèti vien klimato kaitos, nereprodukuojamų mineralinių išteklių išsekimo problemas. Tai keičia ekonominio suverenumo turini.

Pagrindinè grèsmé nacionaliniam ekonominiam saugumui - asimetrinė šalies padètis pasaulinėse žaliavų ir prekių rinkose, priklausomybè nuo vieno ar kelių partnerių turint ekonominių išorès ryšių (tiekẻjų, rinkų, kreditorių ir kt.). Kaip kiekviena grèsmè, tokia priklausomybè siūlo ir savo žalingo poveikio neutralizavimo būdus, tačiau kol grèsmių identifikavimas nèra vienareikšmišskas, juolab nèra sutarimo ir dèl priemonių, kuriomis grèsmès ekonominiam saugumui turètų būti mažinamos ir šalinamos.

Straipsnyje remiamasi ekonominès integracijos teorija, išplètota jos kūrejjų B. Balassos, F. Machlupo, J. Vinerio darbuose, daugiausiai skirtuose tarptautinès prekybos plètrai, ir R. Mundello sukurta optimalios valiutos erdvės teorija, skirta aukštesnei monetarinès valstybių integracijos pakopai. Ekonominès integracijos tyrimas apribotas procesais ES viduje, t. y. netiriamas jos poveikis ES ekonominiams santykiams su išore (taigi, ir prekybos iškreipimo problema ir euro poveikis tarptautinei valiutų sistemai).

Straipsnị sudaro du skyriai. Pirmame skyriuje pateikiama trumpa mažųjų valstybių ekonominès politikos specifika, apibūdinama dabartinè finansų ir ekonomikos krize ir pokrizinis laikotarpis ir identifikuojami pokyčiai ES mažųų valstybių ekonomikos aplinkoje. Antrame skyriuje pagrindinis demesys skiriamas euro zonos krizei ir debatams apie jos ịveikimą - straipsnio autorių nuomone, diskusija apie euro zonos krizès priežastis, eigą ir sprendimo būdus leidžia atskleisti naujų reiškinių mažųjų valstybių ekonominės politikos problematikoje ir, gilinantis ị juos, apčiuopti gaires mažujų valstybių ekonominei strategijai koreguoti ir tikslinti. 


\section{Mažos nacionalinès ekonomikos specifika ir krizès paskatinti ES makroekonominès politikos pokyčiai}

\subsection{Globalizacijos poveikis mažos valstybès ekonominei politikai}

Strateginis ekonominis politikos tikslas - užtikrinti šalies ekonomini saugumą. Ekonominio saugumo traktavimas nei teorijoje, nei praktikoje nèra vienalytis, turi variantų. Mūsų nuomone, vieną iš tiksliausių apibrèžimų yra pateikęs Artūras Grebliauskas, akcentuodamas ekonominès sistemos pusiausvyros tvarumo esminę reikšmę: „<...> ekonominis šalies saugumas turi būti suprantamas kaip valstybès ir šalies [ūkio] subjektų sugebejjimas išlaikyti ekonomikos objektų ir sistemų pusiausvyros būseną, reaguojant ị išorines aplinkos sąlygas."

Didžiųjų valstybių ekonominès sistemos pusiausvyra yra didele dalimi jų vidaus ekonominès politikos dalykas, o mažųjų valstybių pusiausvyra yra jų išorès ekonominių santykių padarinys ir jų išorès ekonominės politikos dalykas. Mažos valstybès ekonominès sèkmès garantas - jos dalyvavimas tarptautinėse prekių ir kapitalo rinkose racionaliausiu būdu. Tarptautiné prekyba leidžia specializuotis ir gauti masto ekonomiją net ir mažose šalyse, kapitalo rinkos teikia lěšų investicijoms ir technologinei pažangai. Dèl to maža valstybe tampa priklausoma nuo tų rinkų daug labiau nei didžiosios valstybės. Nors mažųjų valstybių nacionaliniai interesai nèra kuo nors ypatingi (lyginant su didžiųjų valstybių interesais), joms, kaip pažymi Gediminas Vitkus, tenka veikti ypatingomis, mažiau palankiomis sąlygomis². Krizė yra stiprus tokios pusiausvyros sutrikimas, ji iškelia rimtus klausimus mažųjų valstybių ekonominei strategijai.

2010 m. JAV eksporto apimtis prilygo 12,6 proc. šalies BVP', importo

\footnotetext{
${ }^{1}$ Grebliauskas A., „Grèsmių Lietuvos ekonominiam saugumui analizé“, Lietuvos metinè strateginè apžvalga 2002, p. 262.

${ }^{2}$ Vitkus G., „Mažosios valstybès ir jų nacionaliniai interesai“, Lietuvos nacionaliniai interesai ir jos politine sistema. Konferencijos medžiaga, Vilnius, 1994 gruodžio 16-17d., Vilnius: Pradai, 16 p.

${ }^{3}$ Statistikoje eksporto ir importo verte apskaičiuojama pagal visą (bendrają) prekių ir paslaugų vertę, o BVP nusako vien tik atitinkamais metais sukurtą vertę, kuri nẻra lygi visai tais metais sukurtų prekių ir paslaugų vertei, kadangi dalị tos vertès sudaro ankstesniais metais sukurta ir ataskaitiniais metais tik perkelta vertẻ. Todèl negalima sakyti, kad JAV importas sudaré 16 proc. šalies BVP - tiesiog du skirtingi dydžiai. Visa atitinkamais metais šalyje sukurtu prekių ir paslaugų verte turètų būti apskaitoma prie visos

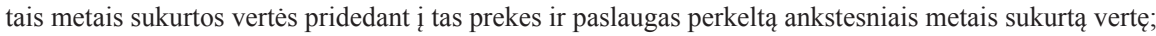
taigi, šalies bendroji produkcija būtų didesnis skaičius nei šalies BVP ir, atitinkamai, importo ir eksporto lyginamasis svoris keletu procentų būtų mažesnis. Toks mažas skirtumas leidžia eksporto ir importo vertės santykị su BVP verte laikyti apytikre eksporto ir importo dalies šalies metiniame produkte išraiška.
} 
- 16,1 proc. ${ }^{4}$ O Lietuvos eksportas 2011 metais sudare 69,6 mlrd. litų, t. y. $65,4$ proc. BVP, importas $-78,7$ mlrd. litų (74 proc. BVP) $)^{5}$. Tai reiškia, kad Lietuvos ekonomika visiškai priklauso nuo ryšių su išore, o JAV ekonomikai tie ryšiai santykinai mažiau svarbūs (jei atsiribosime nuo tokių ryšių gyvybinès svarbos atskiriems ūkio sektoriams). Jei, tarkime, JAV ir Lietuvos importas kuriais nors metais pabrangtų 10 proc., kainų lygis JAV dèl to pakiltų (atsiribojame nuo dèl to vèliau vyksiančių struktūrinių pokyčių) 1,6 proc., o Lietuvoje $-7,4$ proc.

Dèl santykinai mažesnio ekonomikos atvirumo didžiosios valstybės depresijos metu gali sau leisti gausinti pinigų pasiūlą ne tik atpigindamos skolinimąsi arba supirkinėdamas vertybinius popierius antrineje rinkoje, bet ir „spausdindamos" pinigus, tai yra - šalies monopolinio pinigų emitento, centrinio banko, kuriamomis léšomis finansuoti deficitinị valstybès išlaidavimą, kuriuo imamasi padidinti visuminę paklausą ir šitaip truktelti gamybinị aktyvumą. Mažos valstybės to negali - jų namų ūkių ir įmonių paklausa didele (kartais net didesniąja) dalimi tenkinama importu, todèl mažai valstybei visuminès paklausos paskatinimas pinigų pasiūlos pagausinimu tik didintų prekybos balanso deficitą ir keltų riziką šalies valiutos stabilumui (taigi, po to, valiutai nuvertėjus arba ją devalvavus - ir šalies eksporto produkcijos konkurencingumui).

Neišvengiamų išorès ekonominių ryšių (tiek pasitelkiant energijos išteklius, žaliavas, investicines prekes, tiek realizuojant produkciją) svarba rodo ỉ priklausomybę nuo pasirinktų tiekejjų ir pirkẻjų, kartu ir padiktuoja sprendimą: atviros ekonomikos valstybės turi siekti kiek įmanoma diversifikuoti savo išorinès pasiūlos ir paklausos partnerius ir siekti abipusio tų ryšių liberalizavimo laisvos rinkos principais. Tik tokiomis sąlygomis šalies ūkio subjektų, sektorių ir visos ekonominès sistemos pusiausvyra yra santykinai tvari ir dinamiška. Ekonomikos sferoje būtent tas santykinai daug didesnis priklausomumas nuo išorès veiksnių ir reikalauja mažųjų valstybių ekonominès politikos specifikos. Joms kur kas aštriau iškyla ekonominès integracijos klausimas.

Ekonominė integracija žymiai palengvina mažujuu valstybių produkcijos patekimą $\mathfrak{i}$ rinkas, tuo pačiu paskatina ir apskritai didesnị ekonomini bendradarbiavimą. Integracija taip pat palengvina išoreje besiformuojančių neigiamų ekonomikos veiksnių amortizavimą. Taigi, ir ekonominès naudos, ir ekonominio saugumo požiūriu mažoms valstybėms ekonominė integracija

\footnotetext{
${ }^{4}$ Statistics Pocket Book, European Central Bank, January 2012, p. 7.

${ }^{5}$ Lietuvos statistikos metraštis, Lietuvos Statistikos departamentas, 2012, p. 375.
} 
vertintina teigiamai. Tačiau dalyvavimas daugiašalëje ekonominèje struktūroje su neišvengiamu didžiųų valstybių dominavimu tos struktūros institucijose reikalauja keisti nacionalinès ekonominès politikos turinị: stiprinti jos adaptacinę funkciją ir teikti pirmenybę tolesnei regioninei (pasaulio mastu - lokalinei) integracijai.

Tokios tendencijos - vidaus ir išorès politikos susipynimas ir regioninio bendradarbiavimo intensyvejjimas - būdingos visoms valstybių viešosios politikos sritims. Tačiau pastebimi ir specifiniai reiškiniai - valstybių ekonomineje veikloje šios tendencijos kur kas stipresnès nei kitose tautu (nacijų) veiklos srityse, todèl valstybių politikos darbotvarkèse jau įrašyti ir igyvendinami ekonominès integracijos darbai, o kitose viešosios politikos srityse toks integracijos klausimas tebera vien akademinio intereso dalykas. Todèl dabartiniame ekonominès globalizacijos etape ekonominé politika turi tendenciją atsišakoti nuo kitų suverenios valstybès politikos elementų. Ką reiškia toks atsišakojimas mažųjų valstybių politikai - didelis ir sudètingas klausimas.

\section{2. Ūkio krizè pasaulyje ir Lietuvoje}

Nors ekonomikos rida po II pasaulio karo išliko ciklinè, jos svyravimas žymiai sušvelnèjo. Kai XX a. pabaigoje kilo rimtesni ūkio sutrikimai (1992 metų „tekilos“ krizė Meksikoje, 1997 metų krizė Pietryčių Azijos šalyse, 1998 metais - Rusijoje ir Argentinoje), tai buvo laikoma pasaulio ekonomiką ištikusiu fenomenu. 2007 metais ekonominè krizè smogè labiausiai išsivysčiusioms pasaulio šalims. Krizès mastai sukrètė pasaulio ekonomiką. Pirmą kartą po II pasaulinio karo planetos ekonomika susitraukè - 2009 metais pasaulio BVP sumažèjo 0,6 proc., tarp jų ES ūkis smuko 4,2 proc., JAV - 3,5 proc. ${ }^{6}$

Tai buvo sisteminè krizè. Rinkos mechanizmo prigimtinès, "genetinès“ ydos ịveikè nacionalinių ir fragmentiškai veikiančių tarptautinių prekybos ir finansų institucijų reguliavimą, prasiveržè laisvo kapitalo judejjimo kanalais ir surengè galop tikrą „valkirijų puotą“. Kaip pagrịstai pažymi N. Roubini ir S. Mihmas, neteisinga per pasauli nuvilnijusios krizès priežastimi laikyti JAV antrinių būsto paskolų krizę. Ši galëjo būti tik katalizatorius. Dauguma kitų šalių finansų ir po to visos ekonomikos krizès kilo dèl analogiškos saiką viršijančios būsto kreditų ir statybų ekspansijos ir finansinių investicijų plètros, dèl kurių toms ekonomikoms tereikëjo nedidelio stumtelëjimo, kad atsidurtų jau nebeišvengiamoje duobeję ${ }^{7}$.

\footnotetext{
${ }^{6}$ IMF, World Economic Outlook, April 2012, p. 190.

${ }^{7}$ Roubini N., Mihm S., Crisis Economics: A Crash Course in the Future of Finance, New York: The Penguin Press, 2010, p. 127.
} 
Pasaulinę finansų krizę sukèlè pernelyg liberali tvarka pasaulio finansų sistemoje -pusiausvyrą sutrikdè nevaldomas ažiotažas nekilnojamojo turto ir kredito rinkose, veikiant nepažabotam privačiam interesui naudotis kaistančia konjunktūra. Pasauliné finansų sistema, kaip sako N. Roubini ir S. Mihmas, "supuvo iš vidaus"

Būtent privataus kapitalo rinkas tenka nurodyti kaip šios krizès, dabar jau vadinamos Didžiąja recesija, židinị. Daugiametis ir perviršinis viešojo sektoriaus deficitas buvo tik Graikijoje; kitos euro zonos ir euro neįsivedusios ES šalys prieš krizę pasižymèjo kredito ekspansija būtent privačiame sektoriuje, kurio problemos vèliau sukèle deficitus ir šalių biudžetuose. Nuo euro ivvedimo 1999 metais iki finansinių krizių ES šalyse 2008 metais bankų kreditai ir privataus sektoriaus skolos augo dideliais tempais ${ }^{9}$. Tik viešajame sektoriuje (euro zonos šalyse) skola ne tik nedidejjo, bet net sumažèjo - nuo 72 iki 68 proc. BVP. Valstybių finansai tapo deficitiniai tik prasidejus finansų krizei, nes, pirma, teko gelbèti susvyravusius bankus ir, antra, susitaikyti su išlaidas didinančiu savaiminių stabilizatorių veikimu, kai krizei stabdant ūkio plètrą mažejo biudžeto pajamos ir didejo išlaidos ${ }^{10}$. „Kaip įsitikinome krizes metu“, rašo vieno tyrimo autoriai, „privatūs issipareigojimai greitai gali tapti viešojo sektoriaus skola"11.

Mažose Baltijos šalių ekonomikose šie ekscesai pasireiškẻ dar didesne amplitude. Privataus sektoriaus skolinimasis Lietuvoje 2003-2007 metais augo 37 proc. kasmet. Realios (nominalios atemus infliaciją) trumpojo laikotarpio paskolụ palūkanos nuo $2005 \mathrm{~m}$. tapo neigiamos ir liko tokios iki 2008 metu imtinai; 2007 ir 2008 metais jos buvo neigiamos ir ilgojo laikotarpio paskolų. Būsto kainos kasmet vidutiniškai didejo 26,5 proc. Viešieji finansai visą laiką buvo deficitiniai - vyriausybès skolinosi ir liejo pinigus i ekonomiką, jai jau akivaizdžiai keletą metų kaistant ir artejjant prie krizès. Nedarbas, kaip ir reikèjo laukti, kai toks ažiotažas, sumažejo nuo 16,4 proc. 2000 metais iki 4,3 proc. 2008 metais. Bankų pelningumas pasiekè neregètas aukštumas - 2006-2007 metais nuosavo kapitalo grąža

\footnotetext{
${ }^{8}$ Ten pat, p. 272.

${ }^{9}$ Kaip primena N. Robini ir S. Mihmas, dar 2005 metais savaitraštis The Economist apskaičiavo, kad išsivysčiusiose šalyse vien 2000-2005 metų laikotarpiu gyvenamųų namų bendroji vertė padvigubèjo (padidejo 40 trln. dolerių). (Roubini N., Mihm S., Crisis Economics: A Crash Course in the Future of Finance, New York: The Penguin Press, 2010, p. 126).

${ }^{10}$ De Grauwe P,. „A Mechanism of Self-destruction of the Eurozone“, Intereconomic, 2010, No.6, p. 344.

${ }^{11}$ Nacarino R.C., De Corte S., Freudenstein R., „Democracy and legitimacy in an European Union“,

CES, October 2012, p. 4.
} 
bankų sektoriuje buvo atitinkamai 21,4 ir 27,3 proc. ${ }^{12}$ Bankų klientams suteiktų paskolų suma nuo $8 \mathrm{mlrd}$. litų 2002 metų pabaigoje pašoko iki 71 mlrd. litų baigiantis 2008 metams ${ }^{13}$.

Visa tai sukèlè ekonomikos perkaitimą. Lietuvos banko specialistų vertinimu, 2000-2007 metų laikotarpiu šalies ūkis augo vidutiniškai 8 proc. per metus, ir tai viršijo jo potencialias galimybes; infliacijos nesukeliantis augimas galëjo būti, jų nuomone, tik 5-5,5 proc. per metus ${ }^{14}$. Tokị spartų augimą pakurstė kredito ekspansija, kuri, savo ruožtu, tapo įmanoma Lietuvos bankams pradejus intensyviai įvežti kapitalą iš motininių ir kitų užsienio bankų (tai, savo ruožtu, tapo įmanoma Vakarų šalių verslui įsitikinus naujų pokomunistinių nacionalinių ekonomikų, atskilusių nuo subyrejjusios Sovietų Sąungos kontinentinio gamybinio komplekso, gyvybingumu naujomis narystès ES garantijų ir rinkos mechanizmo sąlygomis) ${ }^{15}$.

Didžiausia kreditų ekspansija - nekilnojamojo turto sektoriuje. Taigi, daug iš užsienio įvežamo (bankų ten skolinamo ir Lietuvoje būsto pirkẻjams perskolinamo) kapitalo tiesiogiai neprisidejjo prie šalies gamybinio potencialo didinimo ${ }^{16}$. Kurị laiką ekonomika tikrai sparčiai augo, bet netrukus ji èmé „kaisti“ - viršijo savo potencialą ir tebeaugančios pajamos tapo kainų kilimo veiksniu. $2005 \mathrm{~m}$. infliacija dar buvo 2,7 proc.; $2008 \mathrm{~m}$. ji pašoko iki 10,9 proc. ${ }^{17}$ Darbo našumas Lietuvoje 2000-2006 metais didejo vidutiniškai 6,6 proc. $(2007 \text { m. }-4,7 \text { proc. })^{18}$. Nominalusis darbo užmokestis tuo pačiu laikotarpiu didejjo vidutiniškai 10,6 proc. kasmet $^{19}$.

\footnotetext{
${ }^{12}$ Reiner M., Zauchinger C., ,,Recent Developments in the Baltics and Southeastern European Countries with Low Nominal Exchange Rate Flexibility“, Oesterreichische Nationalbank, Workshops, Proceedings of OeNB Workshops, March 23, 2009, p. 15, 17, 18, 21, 25, 27, 36.

${ }^{13}$ SEB bankas, Lietuvos makroekonomikos apžvalga, 2009 m. kovas, Nr. 35, p. 29.

${ }^{14}$ Kuodis R., Ramanauskas T., „From boom to bust: lessons from Lithuania“, Pinigu studijos, 2009 birželis, Nr.1, p. 96.

${ }^{15}$ Neretai nurodoma, kad pernelyg didelè paskolų injekcija ị Lietuvos ekonomiką, išpūtusi nekilnojamojo turto rinkos ir statybų burbulą, yra pasekmè to fakto, kad didžiausi Lietuvos bankai priklauso didiesiems užsienio bankams. Bankų nuosavybè čia nevaidino reikšmingo vaidmens. Žvelgiant ị kitų šalių patirtị (jau nekalbant apie Islandijos ir Airijos nacionalinių bankų katastrofas), galima būti tikriems, kad tokia neregèto tempo kreditinė ekspansija šalyje vyktų ir šalies bankams priklausant nacionaliniam kapitalui - esant visoms to meto sąlygoms panaudoti lèšas paskoloms tarptautinèje kapitalo rinkoje ir apsisprendus teikti kreditus iki šiol itin mažai kreditus naudojusiam namų ūkių sektoriui.

${ }^{16}$ Kuodis R., Ramanauskas T., „From boom to bust: lessons from Lithuania“, Pinigu studijos, 2009 birželis, Nr.1, p. 100.

${ }^{17}$ Lietuvos Statistikos departamentas, Lietuva skaičiais, 2011, p. 30.

${ }^{18}$ Mackevičius J., Molienè O., „Bendrojo vidaus produkto vienam gyventojui analizès metodika“, Pinigu studijos, 2009 birželis, Nr. 1, p. 34.

${ }^{19}$ Statistical Annex of European Economy, European Commission, Autumn 2012, p. 209.
} 
Reikia pažymèti ir ekonominès politikos neadekvatumą. LRV net bumo laikais planavo ir realizavo vien tik deficitinius biudžetus. $2002 \mathrm{~m}$. Lietuvos viešojo sektoriaus pajamos buvo 17,1 mlrd. litų, išlaidos - 18,1 mlrd. litų; 2008 m. sparčiai didejjančios pajamos daugiau nei padvigubejjo, tačiau vyriausybėms vis tiek reikejjo jas papildyti skolintomis lèšomis, finansuojant dar labiau didinamas valdžios išlaidas (jos padidejo iki 41,7 mlrd. litų 2008 metais) ${ }^{20}$. Pasyvumu pasižymèjo ir Lietuvos bankas. Estijos bankas $2006 \mathrm{~m}$. rudeni pakèlè privalomųjų atsargų normą nuo 13 iki 15 proc., Latvijos bankas 2007 m. - nuo 3 iki 8 proc. ${ }^{21}$ Lietuvos bankas taip ir paliko nepasinaudojęs tokia galimybe.

Kita vertus, iš dalies galima sutikti su Lietuvos banko atstovų pasiteisinimu: „(...) žiūrint retrospektyviai, yra aišku, kad ekonomikos perkaitimas buvo beveik nulemtas. (...) Pasaulinis finansų burbulas ir jo regioniniai ataidai, palydimi su ES siejamais rožiniais lūkesčių, trumparegiškų ekonominių interesų ir rizikos ignoravimu, buvo paprasčiausiai pernelyg galinga jèga, kad būtų buvę galima jai veiksmingai pasipriešinti ${ }^{\text {“22. }}$.

Kaip parodè Estijos pavyzdys (2001-2007 metų laikotarpiu Estijos biudžetas kasmet buvo perviršinis, išskyrus $2001 \mathrm{~m}$., kai deficitas sudare 0,1 proc. $\mathrm{BVP}^{23}$ ), vyriausybių trumparegiškumas ar, priešingai, toliaregiškumas krizès kilimui ir jos eigai mažose Baltijos valstybėse teturejjo nedaug reikšmès - jų visų ekonomika smuko daugiausiai Europoje (kartu su Ukrainos). Estijos ekonomika smuko net giliau nei likusiose Baltijos šalyse: jos apimtis sumažèjo 3,7 proc. jau 2008 metais ir smukimas prasitęsė 2009 m. dar 14,3 proc. $^{24}$ Taigi, bendrasis smukimas nuo 2007 metu lygio buvo net 17,5 proc. Tačiau nacionalinė ekonominė politika nelieka bereikšmè. Estijos toliaregiškumas teigiamai atsilieps artimiausioje ateityje - nesudarusios rezervo ir, priešingai nei Estija, ịbridusios ị nemenką išorinị ịsiskolinimą, Lietuva ir Latvija artimiausią dešimtmetị turès skirti didelę biudžeto pajamų dalị tai skolai administruoti.

\footnotetext{
${ }^{20}$ Lietuvos Statistikos departamentas, Valdžios sektoriaus pajamos ir išlaidos, http://www.stat.gov.lt/lt/ pages/view/?id=2266.

${ }^{21}$ „Recent Developments in the Baltic Countries - What Are the Lessons for Southeastern Europe?“, Oesterreichische Nationalbank, Workshops, Proceedings of OeNB Workshops, March 23, 2009, p. 87, 93.

${ }^{22}$ Kuodis R., Ramanauskas T., „From boom to bust: lessons from Lithuania“, Pinigu studijos, 2009 birželis, Nr.1, p. 103.

${ }^{23}$ European Commission, Statistical Annex of European Economy, Autumn 2012, p. 188.

${ }^{24}$ ECB, Statistics Pocket Book, January 2012, p. 39.
} 


\subsection{Krizè ir slinktys ES makroekonominèje politikoje}

ES mastu nepakankamo finansų rinkų reguliavimo grėsmingumą paryškino pinigų sąjungos sukūrimas. Pinigų sajunga skatina suverenius jos dalyvius, valstybių narių vyriausybes, plačiau naudotis deficitiniu biudžeto išlaidų finansavimu, nes skolintis tampa daug pigiau, o kai galop, jei tuo piktnaudžiauja dauguma sąjungos narių, realios palūkanų normos padideja, jų našta krenta ne vien ribas peržengusioms valstybėms, bet išsidalija visoms pinigų sajungos narėms. Žinoma, prasiskolinusiai šaliai išauga rizikos priemoka jos mokamose palūkanose, bet to negana išvengti finansinès nelaimès. Reikalingos bendrosios taisyklès ir deramas mechanizmas fiskaliniam saikingumui užtikrinti ${ }^{25}$.

Stabilumo ir augimo paktas, priimtas 1997 metais, nustate ir fiskalinès drausmès reikalavimus: vidutinès trukmès laikotarpiu biudžetas turejo būti subalansuotas arba perviršinis, jo nukrypimas ị deficito pusę negalëjo viršyti 3 proc. BVP. Buvo numatytos ne tik perviršinio deficito priežiūros ir perspèjimo procedūros, bet ir sankcijos. Tačiau kai 2003 metais kelios didelès euro zonos šalys pažeide Pakto reikalavimus, Taryboje nugalejo, kaip vienoje iš savo ataskaitų teigia ECB, „nesikišimo“ nuostata ir sankcijos nebuvo pritaikytos. Dar daugiau, 2005 metais Pakto reikalavimai fiskalinei drausmei buvo sušvelninti ir jo veiksmingumas tapo pakirstas ${ }^{26}$.

Manytume, kad pagrindinè priežastis, dèl kurios SAP buvo šiurkščiai pažeistas, buvo ta, kad euro zonos šalys narès nesugebėjo susitaikyti su tokiu staigiu nacionalinès ekonominès politikos transformavimu. Visiškai atsisakę autonomijos vienoje iš dviejų pagrindinių tos politikos dalių - pinigų politikoje, jos neįstengè susiveržti dar ir fiskalinėje politikoje. Reikalaujami pokyčiai joms buvo per staigūs ir per stambūs.

Dar 1999 metais tada Taryboje pirmininkavusi Vokietija pasiūlè pradèti vadinamąji makroekonominị dialogą (kitaip - Kelno procesą), kuriuo būtų užtikrinama geresnè sąveika tarp pinigų, biudžeto, fiskalinès politikos ir darbo užmokesčio politikos ES šalyse. Po kiek laiko tai buvo realizuota periodiškai priimamomis Plačiosiomis ekonominès politikos gairèmis (Broad Economic Policy Guidelines), tačiau jų vykdymą šalys narès, kai kurių autorių teigimu, traktavo daugiau nei neprivalomu ${ }^{27}$.

2008 metų pavasarị, minint ES vadovų tarybos sprendimo kurti EPS

\footnotetext{
${ }^{25}$ The relationship between monetary policy and fiscal policies in the euro area, ECB, Monthly Bulletin, February 2003, p.41-42.

${ }^{26}$ Fiscal Integration in Europe, ECB, April 2012, p. 89.

${ }^{27}$ Howarth D., Loedel P., The European Central Bank. The New Leviathan?, London: Palgrave Macmillan, 2005, p.104.
} 
dešimtmetị, Europos Komisija (EK) jau gerai suvokė pavojus bendrosios valiutos erdvei. Turime aiškiai pripažinti, kalbejjo ta proga EK narys Joaquinas Almunia, kad ES šalių ekonomikų tarpusavio priklausomumas dar niekada nebuvo toks stiprus; todèl ES ir kiekvienos šalies narès labui turime ryžtingai eiti tikro (ang. genuine) ekonominès politikos koordinavimo link ${ }^{28}$. EK narys pripažino, kad nacionalinių biudžetų priežiūra remiantis Stabilumo ir augimo paktu nustatytais viešųjų finansų stabilumo kriterijais turi būti papildyta „makroekonominiais aspektais, išeinančiais už grynai biudžetinių reikalų“29.

Tokio žingsnio dar teko palūkèti. Tik 2011 metų rudenį Taryba ir Europos parlamentas prièmé vadinamajj šešiu dokumentų paketą, kuriuo sustiprinamas Stabilumo ir augimo pakto veikimas, ịvedant naują makroekonominių disbalansų priežiūros procedūrą ir sugriežtinant sankcijas euro zonos valstybėms ${ }^{30}$. Kitaip tariant, šešių dokumentų paketu buvo pasislinkta toliau nei biudžetinės drausmės reikalavimų sugriežtinimas - susitarta dèl gilesnių, biudžetinę pusiausvyrą ardančių priežasčių, susidarančių šalies ekonomikos raidoje, kontroliavimo ${ }^{31}$.

İvesta ir nuoseklesné priežiūros tvarka - vadinamasis Europos semestras. Kiekvienų metų pirmaji pusmetį EK pateiks šalių narių Metines augimo apžvalgas (ang. Annual Growth Survey), kurios bus apsvarstomos ES Taryboje ir Europos parlamente, aptariamos šalių narių, o šalims suteiktos rekomendacijos atsispindès jų po to teikiamose nacionalinèse reformų programose ir Stabilumo (euro zonos narėms) arba Konvergencijos (likusioms ES šalims) ataskaitose. Šios taip pat bus vertinamos, svarstomos ir susilauks Tarybos rekomendacijų, į kurias bus atsižvelgiama, metams baigiantis, nacionaliniuose biudžetuose. Dèl tokių procedūrų apie finansinio išbalansavimo pavojų bus galima ịspèti anksčiau ir užbègti problemoms už akių.

Svarbiausius šalių ísipareigojimus makroekonominès valdysenos sferoje Ekonominès ir pinigų sąungos teisès normomis pavertẻ Sutartis dèl stabilumo, koordinavimo ir valdysenos ekonomineje ir pinigų sąungoje (kartais vadinama Fiskalinio stabilumo sutartimi). Prie jos prisijungè ir ne euro zonos ES valstybès, išskyrus Jungtinę Karalystę ir Čekiją. Jos ịsigaliojimas numatomas, priklausomai nuo ratifikavimo eigos, $2013 \mathrm{~m}$. sausio $1 \mathrm{~d}$., jos reikalavimai perkeliami ị nacionalinę teisę iki $2014 \mathrm{~m}$. sausio $1 \mathrm{~d}$.

\footnotetext{
${ }^{28}$ Almunia J., „EMU @ 10: Successes and challenges of 10 years of Economic and Monetary Union“, European Parliament. Plenary Session, Brussels, May 7, 2008.

${ }^{29}$ Ten pat.

${ }^{30}$ Financial Integration in Europe, ECB, April 2012, p. 97.

${ }^{31}$ Makroekonominių disbalansų procedūros švieslentèje naudojama 10 rodiklių, kuriais remiantis parengiamas ES ịspèjimo mechanizmo pranešimas (Alert Mechanism Report). Tarp to dešimtuko yra tokie rodikliai kaip einamosios sąskaitos balanso trejų metų slenkantinis vidurkis, šalies eksporto lyginamojo svorio pasaulio eksporte pokytis per 5 metus, būsto kainų indekso pokytis, lyginant su vartojimo kainų indekso pokyčiu ir kt.
} 
ES finansų sferos stabilumui stebèti ir teikti išankstinius perspejjimus ¡kurtos (arba pertvarkytos) ir atitinkamos institucijos. Tai pirmiausia Europos sisteminès rizikos valdyba (ang. European Systemic Risk Board), veiksianti makroekonomikos lygiu, ir trys Europos finansų priežiūros institucijos, stebinčios atitinkamas finansų sritis - Europos bankininkystės institucija (EBI), Europos draudimo ir profesinių pensijų institucija (EDPPI) ir Europos vertybinių popierių ir rinkų institucija (EVPRI) ${ }^{32}$.

Pinigų sajungoje tèra dvi alternatyvos tvarkant viešuosius finansus, nulemiančius bendrosios valiutos stabilumą ir patikimumą - arba sąjungos narėms uždraudžiama pažeisti nacionalinių viešųjų finansų pusiausvyrą, arba jos lieka suverenios savo biudžetinèje politikoje, bet pinigų sąjunga turi visą reikiamą mechanizmą ir fondus šalims pagelbèti, kai jos ịklimpsta ị perviršinị prasiskolinimą. Abiem atvejais nẻra jokio pagrindo kalbèti apie absoliučiai suverenią pinigu sąjungos narès fiskalinę politiką - pinigų sąjungoje ji negalima.

Lig šiol Ekonominejje ir pinigų sajungoje to nebuvo. ES sutarties 126 straipsnis skelbia: „Valstybès narès vengia perviršinio bendrojo šalies biudžeto deficito $^{\text {"333 }}$, tačiau to vengimo detales numatantis Stabilumo ir augimo paktas nebuvo vykdomas. Griežčiau reglamentuota fiskalinè drausmè ir sustiprinta gilesnių priežasčių, grasinančių viešųjų finansų pusiausvyros pažeidimu, analizè ir tos analizės atlikimas pagal bendras taisykles ir su EK priežiūra, tikètina, stiprins nacionalinių ekonomikų tvarumą ir konkurencingumą. Individualioms valstybėms EPS narèms (ir kandidatėms) sumažès galimybè ir patrauklumas imtis rizikingų veiksmų makroekonomineje politikoje - tokia bus jų suverenumo praradimo šioje srityje esmè.

Gali atrodyti, kad fiskalinès drausmès didinimo ir finansinio stabilumo stiprinimo priemonès yra neabejotinas žingsnis fiskalinio federalizmo link. Visai logiškai pinigų sajungos šalių narių biudžetų deficito griežtas ribojimas yra palydimas federalinio biudžeto. Tačiau kuriamas Europos stabilumo mechanizmas (ESM) yra veikiau pinigų sajungos centrinio banko valdomas fondas, skirtas teikti paskutinio prieglobsčio paskolas, o ne federalinio biudžeto užuomazga. Sutartyje nurodoma, kad „kaip ir TVF, ESM teiks stabilumo parama bet kuriai ESM narei, kai jos galimybes naudotis iprastomis rinkos finansavimo priemonèmis pablogéja arba kyla rizika joms pablogéti“"34.

\footnotetext{
${ }^{32}$ Komisija priima teisès aktų pasiūlymus griežtinti Europos finansų priežiūrą, Briuselis, IP/09/1347, 2009 m. rugsèjo 23 d., http://europa.eu/rapid/press-release_IP-09-1347_lt.htm?locale=en , 2012-11-27. ${ }^{33}$ Europos Sajungos sutarties ir Sutarties dèl Europos Sajungos veikimo suvestinès redakcijos, Oficialusis leidinys, C 83, 53 tomas, 201003 30, http://eur-lex.europa.eu/JOHtml.do?uri=OJ:C:2010:083:SOM:LT:HTML. ${ }^{34}$ Treaty establishing the European Stability Mechanism, http://www.european-council.europa.eu/ media/582311/05-tesm2.en12.pdf, p. 7., 2012-11-27.
} 
Šis faktas, lygiai kaip ir kaskart sunkiai vykstančios diskusijos dèl naujos daugiametès ES biudžeto strategijos ${ }^{35}$, liudija, kad fiskalinis federalizmas, jo klasikine prasme, ES lieka utopija. Judama ne valstybių narių „finansinès (ar net makroekonominès) federacijos“, bet „reglamentacinès unijos“ kūrimo link, t. y. fiskalinès valdysenos standartizavimo kryptimi.

Tačiau pastebime ir priešinga kryptimi stumiančių veiksnių. Makroekonominès politikos konsolidavimas ves prie politinès federacijos ne suverenumą apribojančiais teisès aktais, bet praktinėmis atsiskaitymų, peržiūrų, rekomendavimo, priekaištavimo ir grasinimo sankcijomis procedūromis, tvarkantis su šalies viešaisiais finansais. Ekonominès politikos suverenumas šiuo atveju mažès dèl to suverenumo ịtraukimo į ES makroekonominę politiką ir atitinkamų ịsipareigojimų ją igyvendinant nacionalinèse ekonomikose.

Nèra abejonių, kad viršnacionalinių institucijų vykdomos sisteminès (makroekonominès) priežiūros galių didèjimas didins ES valstybių narių tarptautinių issipareigojimų lyginamajji svorị, pratęsdamas jų absoliutaus suverenumo mažèjimą ir jo didejjantị sureguliavimą. ES ribose tai gali žadèti virsti nauja kokybe - šalių narių politinès sajungos kūrimu. Vokietijos kanclerè A. Merkel (paskui ją ir EK pirmininkas J. M. Barroso) ne be pagrindo jau prakalbo apie tokią sąjungą, kaip ES ateitį; be tokios sąjungos visi makroekonominès politikos principų ir nuostatų unifikavimai esą gali pasirodyti neveiksmingi ${ }^{36}$.

Tačiau galimas ir kitoks vyksmas: ekonominès sajungos formavimasis dar ilgai gali vykti kaip santykinai autonomiškas (politinės integracijos atžvilgiu) procesas. Idejjos apie ES ekonominę vyriausybę ir ES ekonominę federaciją nèra be pagrindo. Suverenios ES valstybès gali tokiomis ir likti, kartu jose funkcionuojant nacionaliniams suvienytos ekonomikos (jungtinès ES ekonomikos) padaliniams. Liks ir nacionaline ekonomine politika bet jau kaip vieno bendro projekto realizavimo atitinkamose valstybèse priemone (analogiškai dabar euro zonos šalyse tų šalių nacionalinių bankų vykdomai bendrajai pinigų politikai) ${ }^{37}$.

Medžiagos stebèti šių alternatyvių procesų vyksmą ir perspektyvas teikia Ekonominès ir pinigų sąungos raida.

\footnotetext{
${ }^{35}$ Šiuo metu vykstančios ir kažkiek stringančios diskusijos dèl 2014-2020 metų biudžeto perspektyvos rodo, kad prieš keletą dešimtmečių nustatyta maksimali ES biudžeto apimtis - 1,24 proc. ES bendrujjų nacionalinių pajamų - ne tik ilgai dar nebus padidinta, bet ir liks nepasiekta; naujasis biudžetas, manoma, sudarys apie 1 proc. BNP.

${ }^{36}$ Germany's Chancellor Merkel urges EU political union, http://www.bbc.co.uk/news/world-europe-18350977, 2012-11-30.

${ }^{37}$ Šios alternatyvos aktualumą geriausiai paliudija plataus atgarsio sulaukusi Didžiosios Britanijos ministro pirmininko D. Camerono kalba $2013 \mathrm{~m}$. sausio 23 d., kurioje akcentuojamas ekonominès unijos naudingumas ir griežtas bet kokios politinès integracijos atmetimas (http://www.ft.com/cms/s/0/259ef844653d-11e2-a3db-00144feab49a.html\#ixzz2InSXDc3b, 2013-01-24).
} 


\section{Pinigu sajungos ypatybès ES ir jos kūrimo neišbaigtumas}

\subsection{EPS konstrukcijos trūkumai ir pinigų sajungos kūrimo problemos}

Vienas iš plačiausiai žinomų globalizacijos indeksų yra vadinamasis Dreher (KOF) globalizacijos indeksas, kuriuo įvertinamas globalizacijos poveikis šalies vystymuisi, šalies padètis globalizuotame pasaulyje. Mokslininkai mano, kad mažos šalys labiau globalizuojasi. Baltijos šalių globalizacijos indeksų analizė patvirtina, kad jose globalizavimosi lygis yra gana aukštas ir yra stipriai susijęs būtent su ekonomine plètra ${ }^{38}$.

Neišnaudoto pinigų sąjungos potencialo suvokimas ateityje situaciją gali pakeisti iš esmès. Turime omenyje suvokimą, kad bendrosios valiutos nefunkcionavimas visoje ES teritorijoje trukdo ES kaip visumos ekonomikos plètrai galimybėms konkurencingai plaukioti pasaulinès ekonomikos vandenynuose. Skirtingas galių santykis daro ịtaką ir ekonominiam išprusimui, ir ekonomikos suvokimui. Ekonominès politikos ideologiją ir teorinius pagrindus dabar diktuoja pačios integracijos rezultatai - viršnacionalinès ES institucijos.

ES didžiosios šalys „,signatarès“ dešimtmečiais integravosi iš lèto evoliucionuodamos. Naujosioms šalims narems yra taikomas griežtų ir principinių taisyklių integracijos modelis. Atsirado viršnacionalinės institucijos, kurios, priklausomai nuo atskiros šalies narès ekonominių interesų galios, vienoms šalims narèms sudare naujų galimybių, o kitas - suvaržè. Krizès metu dar labiau išryškẻjo skirtingi šaliu prioritetai, nebèra tabu ir EPS iširimo tema. Mažos atviros ekonomikos šalis, sutikusi integruotis ị bendrąją prekybos erdvę, be apribojimų atvèrusi savo sienas finansinių srautų cirkuliacijai, tačiau negavusi teisès būti visateise EPS dalyve, neišvengiamai susiduria su rimta problema užtikrinti ekonomikos stabilumą.

Dar 1990 m. spalio mèn. priimtoje pirmojoje LRV programoje buvo nurodyta, kad „isitraukimas ị Europos ekonominès erdvés kūrima“" pareikalaus iš šalių paaukoti tam tikrą savo suverenumo dalį, tačiau „ne visos valstybès pasirengusios tokiam žingsniui“ ir "yra susirūpinusios dèl didžiuju Vakaru

\footnotetext{
${ }^{38}$ Pekarskiene I., Susniene R., ,An Assessment of the Level of Globalization in the Baltic States“, Engineering Economics, No.22 (1), 2011, p.58-68.
} 
Europos valstybiu dominavimo Europos Bendrijoje ${ }^{\text {"39. }}$. Praejjus dešimtmečiui ne vienas žinomas pasaulio ekonomistas įspejo, kad naujosios šalys narès neturètų būti atskirtos nuo EPS raidos reikalų ${ }^{40}$. Anksčiau tam tikrų nacionalinio suvereniteto nuostatų atsisakymas buvo tik derybų įrankis, dabar tai vadinama "stipresniu bendradarbiavimu“ ir tapo ES sutarties oficialaus žodyno dalimi ${ }^{41}$.

Pinigų sąjungos esmę sudaro du bruožai: bendroji valiuta (kitas variantas - nekintamu kursu ir neterminuotai susietos nacionalinès valiutos) ir bendroji pinigu politika. EPS funkcionavimo kokybei reikšmingi yra šie veiksniai: bendrieji interesai; institucijų orientacija ị bendruosius, o ne vien tik ị euro zonos interesus; „zuikiavimas“; taisyklių ir normų laužymas; institucijų pajègumas adekvačiai reaguoti i EPS kaip viešosios gèrybès „gadinimą"; biuropatologijos reiškinys (užsidarymas vidaus interesų rate, o išorinių (visuotinių) interesų pavertimas vidaus tikslų igyvendinimo priemone ${ }^{42}$.

Šiuo metu turima euro zonos šalių galia trukdo išspręsti dilemą, kaip esant euro zonai EPS viduje priimti sprendimus pagal ES sutarties nuostatus ir taip pat išsaugoti visų ES šalių narių (o ypač mažųų ekonomikų) vienodo traktavimo principo dvasią. Kyla pagrịsti nuogąstavimai, kad euro zonai naudinga sumažinti naujųjų šalių narių konkurencingumą ir patrauklumą investicijoms.

Kol ES „Žaidžia“ su vidaus problemomis ir konvergencija tarp euro zonos ir ne euro zonos, tarptautiniu lygiu euras darosi vis svarbesnis. Vadinasi didèja ir atsakomybè, ir nauda, kurią galètų atnešti ES ekonomikos politikos koordinavimas. Ilgesnị laikotarpị būnant už euro zonos ribų didèja tikimybė, kad neigiamą įtaką darantys ekonomikos šokai nepagrịstai atitolins naująsias šalis nares nuo dalyvavimo euro zonoje, lems aukštesnį infliacijos ir einamosios sąskaitos deficito lygi.

Krizė privertė ne tik teorijoje, bet ir praktikoje pripažinti, kad finansinès integracijos nauda nebūtinai paskirstoma šalims vienodai, kad finansų sistemos integracija tiesiogiai veikia rinkos efektyvumą, o jei ji tampa veiksminges$n \dot{e}^{43}$, tai stiprejja ir viešųjų interesų užtikrinimas visoje sistemoje ${ }^{44}$.

\footnotetext{
${ }^{39}$ Lietuvos Respublikos Vyriausybès (LRV) programa, [Action Report of the Government of the Republic of Lithuania], 199010 11, http://www.lrv.lt/bylos/vyriausybes/po_1990_1_programa.pdf .

${ }^{40}$ Mundell R. A., ,Exchange Rate Arrangements in Central and Eastern Europe“ in Arndt S., Handler H., Salvatore D., Eastern Enlargement: the Sooner, the Better?, Vienna: Austrian Federal Ministry of Economic Affairs and Labor, 2002.

${ }^{41}$ Moravscik A., Europos pasirinkimas: socialinis tikslas ir valstybès galia. Nuo Mesinos iki Mastrichto, Vilnius: Margi raštai, 2008.

${ }^{42}$ Gylys P., Ekonomika, antiekonomika ir globalizacija, Vilniaus universiteto leidykla, Vilnius, 2008.

${ }^{43}$ Hartmann P., Maddaloni A., Manganelli S., ,The Euro Area Financial System: Structure, Ingeration and Policy Initiatives“, Working Paper Nr.230, ECB, May 2003.

${ }^{44}$ Kropas S., Kropienè R., Europos pinigai, Vilnius, 2005.
} 


\subsection{Kaip EPS "taisymas ir tobulinimas“ gali atsiliepti mažosioms ES šalims narèms}

Mažosios šalys integracijos pradžioje vykde politiką, kuri atitiko ES normas, nes buvo siekiama ES narystės. Teigiama, kad jos turejo sąlygas ir galimybes pasinaudoti geriausiai veikiančių viršnacionalinių (ES) institucijų ir kitų ES šalių narių vidaus institucijų „patirties importu“. Mažoms šalims integracijos metu naudinga perimti jau egzistuojančių institucijų struktūrą, taisyklių ir tvarkų kūrimo modelius. Esant tokioms aplinkybėms, institucijų modeliams kurti mažos šalys savo viduje sunaudojama mažiau išteklių. Per ES sutarčių sistemą i mažąsias ES šalis nares yra „importuojamos“ ir naujos reglamentavimo sistemos, ir net ideologija. Tai yra pozityvu su sąlyga, jei šios sistemos yra išbandytos ir kokybiškos, o ideologija padeda gerinti gyvenimo kokybę ${ }^{45}$.

Turime atkreipti dèmesį, kad pastarujų metų sprendimai dèl EPS visų pirma numato gilesnę integraciją tarp euro zonos šalių, nors su 1992 m. Mastrichto sutartimi gimusi ES pinigų sistema, mūsų nuomone, nebuvo sumanyta tokiai ilgai ir geografiškai plačiai euro valiutos plètrai. Prieš 20 metų euro integracija buvo matoma kiek kitaip. Dažnas analitikas primiršta, kad formaliai visos ES šalys narès yra EPS narès, tik su laikina išlyga dèl euro įsivedimo. Nors dauguma naujų mechanizmų galios tik euro zonos viduje, tačiau ne euro zonos šalys jau beveik dešimtmetị yra atsisakiusios galimybės vykdyti savarankišką pinigų politiką (tiek, kiek tai gresia Stabilumo ir augimo pakto reikalavimų pažeidimu).

Prieš apžvelgdami EPS valdymo ir funkcionavimo tobulinimo būdus, norètume priminti ankstesnių pinigų sąjungų nesèkmių priežastis:

- nebuvo politinès integracijos;

- nebuvo pakankamo bendro biudžeto;

- nesiremta pinigu politikos bendru funkcionavimo principu;

- trūko atsparumo neigiamam išorès krizių poveikiui ${ }^{46}$.

Mažoms šalims tenka laviruoti tarp dviejų interesų koncepcijų, kurių požymius galima ịžvelgti ir ES raidoje. Viena jų - tai didysis universalizmas arba vadinamasis visapusiškumas, kai sąžiningai elgiamasi su visomis šalimis (kokio dydžio jos bebūtų), kai nusistatytos taisyklès ir principai galioja vi-

\footnotetext{
${ }^{45}$ Kaul J., Grunberg J. and Stern M., eds., Global Public Goods: International Cooperation in the 21st century, New York, Oxford University Press, 1999.

${ }^{46}$ Kropas S., Kropienè R., Europos pinigai, Vilnius, 2005.
} 
siems, nieko neišskiriant ir neatliekant jokios klasifikacijos pagal ekonomikos dydị. Kita koncepcija vadinama nacionaliniu partikuliarizmu (orientavimasis ì vienos šalies interesus) - kai sąžiningai elgiamasi su kiekviena šalimi atskirai ir kai šalių santykiai reglamentuojami papildomai nustatant regioninio (globalaus) teisingumo ir nešališkumo taisykles ${ }^{47}$.

Tommaso Padoa-Schioppos grupė savo ataskaitoje apie veiksmų planą, kuriant fiskalinę sąjungą ES, teikia tokius pasiūlymus:

- bendrosios rinkos skatinimui reikia, kad euro zona taptų visiškai integruota ekonomine erdve, todèl yra būtini vidiniai instituciniai pertvarkymai. Būtina ieškoti sprendimo diversifikuojant integracijos laipsnius. Tai reiškia, kad reikia pereiti prie naujos Tarpvyriausybinès sutarties, sukurti naują ES 17 struktūrą, kuri veiktų paraleliai ES 27 struktūrai ir būtų su ja glaudžiai susijusi;

- šalia ES biudžeto reikètų sukurti ciklinio stabilizavimo draudimo fondą, kurị tiesiogiai kontroliuotų nacionaliniai parlamentai;

- siekiant subalansuoti fiskalines teises ir pareigas, reikia sukurti ES skolos valdybą (ESV), per kurios veiklą sudaryti šalims galimybę lanksčiai refinansuoti skolą. ESV neturètų tiek teisių kaip finansų ministerija, tačiau ir nebūtų tik ES valiutos fondas. ESV turètų vadovauti „euro zonos finansų ministras“. Nacionalinius parlamentus reiketų ịtraukti ị teisinę ESV aplinką priimamiems sprendimams derinti. Tiksli šios institucijos sudetis - tai platus politinis klausimas;

• euro zonos bankų sajungos sutvirtinimui būtina sukurti euro zonos bankų priežiūros instituciją ir jai suteikti mikrolygio rizikos ribojimo priežiūros galią, taip pat ịsteigti agentūrą, kuri administruotų ES indẻlių draudimo fondą. Šiuo metu būtų labai sunku nustatyti tokias finansinio stabilumo euro zonoje taisykles, kurios nesukeltu pavojaus bendros finansų rinkos funkcionavimui, todèl reikia skubinti šių institucijų ịkūrimą. Be to, ji būtų daug labiau nepriklausoma nuo nacionalinių galios centrų už dabar esančias nacionalinès priežiūros institucijas. Euro zonos bankų sąungą galima kurti pagal dabartinę ES sutartị, remiantis euro zonos narių bendradarbiavimu - bendradarbiaujant glaudžiau arba sudarant tarpvyriausybinius susitarimus;

- pasiūlymai turi būti iggyvendinti kaip paketas, kaip visuma ir vienu metu, nes visas euro zonos nares ,jungia ne tik bendra valiuta, bet ir bendras

\footnotetext{
${ }^{47}$ Kaul J., Grunberg J. and Stern M. eds., Global Public Goods: International Cooperation in the 21st century, New York, Oxford University Press, 1999.
} 
likimas", o jas valdančios institucijos turi „pagaliau pateisinti vilti, kad ekonomine politika yra bendro intereso reikalas ${ }^{448}$.

Siekiant išvengti konkurencijos kraštutinumų, kai mažos ekonomikos ypač aštriai konkuruoja dẻl tiesioginių investicijų, reikalingos aiškesnès regioninès (ES) taisyklès dèl priemonių užsienio investicijoms pritraukti, taip pat tobulesnès taisyklès dèl aplinkos ir darbo standartų. Skiriant didesnị dèmesị bendrųjų taisyklių aiškumui, susidarytų galimybès atsisakyti reglamentuojamos konkurencijos. Mažų ekonomikų šalys yra ypač suinteresuotos teisingomis žaidimo taisyklemis, nes investuotojai visada linkę mažas šalis spausti taikyti mažesnius reikalavimus. Mažos šalys būgštauja dẻl susitarimų euro zonoje, nes, pasinaudojus „klubo“ sprendimais, gali būti ginami politiškai stiprių protekcionistinių galios centrų interesai didžiosiose šalyse, iš mažųjų šalių atimant galimybę patekti ị jų rinkas ${ }^{49}$. Iš euro zonai nepriklausančių šalių finansinè veikla plečiasi euro zonos šalių link ir koncentruojasi būtent didžiausiose euro zonos ekonomikose. Netinkamai reaguojant $\mathfrak{i}$ krizès padarinius ES mažosiose šalyse narèse, kenkiama ES tolesnei raidai ir jos kaip globalios rinkos dalyvès galiai ${ }^{50}$.

Kaip atnaujinti euro zonos plètros strategiją siūlo ir mokslininkai iš BRUEGEL instituto:

- Analizuojant ekonominius rodiklius atskiroje šalyje atsižvelgti i padèti visoje ES.

- Konvergencijos kriterijai tapo visiškai netinkami, nes laikantis dvieju kriteriju - infliacijos ir deficito - gaunami prieštaringi rezultatai.

- Euro zonos narius priimti atlikus ekonomini narystés euro zonoje sąnaudų ir pajamų ịvertinimą, nustatant gaunamą naudą ir ilgalaikio tvarumo tikimybę.

- Nustatyti išankstines sąlygas, kokį valiutos keitimo kursą turẻdami turètų prisijungti potencialūs nariai.

- Nepaisant konvergencijos kriterijų vykdymo būklès, šalys turètų galèti rinktis, kada ịsivesti eurą.

- Euro ịvedimui taikomi kriterijai turi užtikrinti, kad ekonominẻ logika būtų aukščiau ir už politinę logiką, ir už teisinę logiką̧51.

\footnotetext{
${ }^{48}$ „Completing the Euro. A road map towards fiscal union in Europe“, Report of the "Tommaso PadoaSchioppa Group", Notre Europe, June, 2012.

${ }^{49}$ Kaul J., Grunberg J. and Stern M., eds., Global Public Goods: International Cooperation in the 21st century, New York, Oxford University Press, 1999.

${ }^{50}$ Pisani-Ferry J., Posen A.S., „The Euro at Ten: The Next Global Currency?“, Bruegel, June 2009.

${ }^{51}$ Sapir A., „Bruegel Memos To The New Commission, Europe’s economic priorities 2010-2015“, 2009.
} 
Dažnai girdime klausimą, ar geriau būti ar nebūti euro zonos nariu krizès metu? S. Skrzypeko nuomone, kiekvienos šalies atsakymas būtų skirtingas: „Situaciją euro zonoje turètų koreguoti kainos, darbo užmokestis ir našumas, o tai sudètingesnis procesas už situacijos koregavimą naudojantis valiutos kursu. Tai taip pat galioja šalims, kurios nepriklauso euro zonai, bet savo valiutas susiejo su euru. Tačiau jei turètume rinktis tarp buvimo euro zonos nare ir buvimo ES nare, kuriančia valiutą, susietą su euru, atsakyti būtų paprasta - geriau būti euro zonos nare ${ }^{\text {“52 }}$. Realybejje viskas sudètingiau. "Joks bendros valiutos režimas nèra naudingas visoms šalims visais laikais“, teigè Jeffrey Frankel ${ }^{53}$, todèl neužtenka rinktis vien tik tarp svyruojančio ir fiksuoto valiutos kurso. Taip yra todèl, kad euras jau yra tarptautinè valiuta, tad euro ir kitos pasaulinès valiutos - dolerio - santykio kitimas gali didinti skirtumus tarp ES šalių ir sudaryti problemų šalims, kurios yra pririšusios savo valiutą prie euro, taip pat paveikti eurą ịsivesti siekiančių šalių konkurencingumą ${ }^{54}$.

Oportunizmo visoje ES kontrolè reikalinga ypač mažoms šalims, nes taisyklių ir prekybos susitarimų priežiūra ribotų didžiųjų i̇monių monopolistines galias. Tik didžiosios ES šalys gali pasinaudoti rinkos netobulumu ir ydomis, nes tarptautinès prekybos monopolijos paprastai įsikuria didžiųjų ekonomikų šalyse. Jos užima rinką ne tik regionineje, bet ir pasaulinejje prekyboje, todèl konkurencijos jų produktams mažųjų šalių rinkose praktiškai nèra. Tokiais atvejais didžiosios šalys gali imti vykdyti tokią prekybos politiką, kuri stiprintų būtent jų įmonių konkurenciją rinkoje arba būtent joms gerinti prekybos sąlygas ${ }^{55}$. Mažos šalys, argumentuodamos būtinybe plètoti savo ekonomikas ir vykstančia neišvengiama internacionalizacija už ES ribų, turi siekti reformuoti dabartinius EPS valdymo matmenimis:

- Mažos šalys turètų būti geriau atstovaujamos viršnacionalinių institucijų vadovybèse.

- Visuose galios centrų forumuose ir formatuose turi dalyvauti ir mažųjų šalių atstovai.

- Nespręsti šiandienos problemų būsimų kartų sąskaita.

\footnotetext{
${ }^{52}$ Nowotny E., Mooslechner P., Ritzberger-Grünwald D., ,The Euro and Economic Stability. Focus on Central, Eastern and South-Eastern Europe“, Oesterreichische Nationalbank, Austria, 2010.

${ }^{53}$ Frankel, J. A., „No Single Currency Regime is Right for All Countries or at All Times“, Graham Lecture, Princeton University, 1999.

${ }^{54}$ Nowotny E., Mooslechner P., Ritzberger-Grünwald D., ,The Euro and Economic Stability. Focus on Central, Eastern and South-Eastern Europe“, Oesterreichische Nationalbank, Austria, 2010.

${ }^{55}$ Kaul J., Grunberg J. and Stern M., eds, Global Public Goods: International Cooperation in the 21st century, New York, Oxford University Press, 1999.
} 
- Stiprinti pinigų integracijos stebėseną.

- Naujosiose viršnacionalinėse institucijose būtina užtikrinti tinkamą visų problemų sprendimą ir interesų atstovavimą ${ }^{56}$.

ES šalių narių, o ypač euro zonos šalių narių, finansai siejasi vis glaudžiau, tačiau didžiosios šalys išsaugo esminių sprendimų iniciatyvą ES. Reikalavimai įvesti sankcijas finansinei drausmei liudija viršnacionalinès jurisdikcijos plètojimą EPS, taip pat artëjama prie ES ekonominès vyriausybès steigimo ${ }^{57}$.

Vykdydamos vidaus reformas mažos šalys sudaro susitarimus regioniniame (ES) lygmenyje ir tokiu būdu susilpnina ịvairių galios centrų šalies viduje pasipriešinimą reformoms. Tačiau mažosioms šalims iškyla kita problema - tai silpnos jų pozicijos daugiašaleje aplinkoje, t. y. jos neturi pakankamai išteklių aktyviai dalyvauti įvairaus formato susitikimuose ir veiksmingai ginti savo interesų sudètingose ir ilgai trunkančiose derybose $\mathrm{e}^{58}$. Tokias problemas galima išspręsti ne per spontaniško mechanizmo veikimą, o per programini režimą, kurị taikant veiktų naudą didinanti strategija, verčianti ES institucijas atskleisti mažosioms šalims visą informaciją ${ }^{59}$.

Žmonès iš integracinių procesų tikèjosi stabilumo, teigiamo poveikio ekonomikos augimui ir rinkoms. Taigi, pinigų sąungos struktūros stabilumui reikia trijų sąlygų:

- bendro krizės sprendimo mechanizmo ES,

- procedūrų rinkinio, kaip tvarkytis su šokais šalių viduje,

- bendros bankų priežiūros institucijos ${ }^{60}$.

Krizių valdymo sistemoje turi dalyvauti ir privatus sektorius, t. y. regioninès ir pasaulinės finansinès institucijos, ị privatųji sektorių orientuoti bankai ${ }^{61}$.

Integracija nevyksta mechaniškai ir spontaniškai, veikiant vien tik rinkos jègoms. Šiam procesui aktyvinti naudojami režimai, t. y. programiniai susitarimai ir veiksniai. EPS su ne euro zona ir euro zona savo viduje yra ne pinigu sajunga, o tiesiog fiksuoto valiutos kurso režimas, todèl euro zonai išlikti dabartine forma ateityje nepavyks ${ }^{62}$. Matome, kad teisinių prielaidų mechanizmas po

\footnotetext{
${ }^{56}$ Ibidem

${ }^{57}$ Čičinskas J., „Euro zona gelbejjasi“, Balsas.lt, 20100329.

${ }^{58}$ Kaul J., Grunberg J. and Stern M. eds., Global Public Goods: International Cooperation in the 21st century, New York, Oxford University Press, 1999.

${ }^{59}$ Tresch R. W., Public Sector Economics, Palgrave Macmillan, 2008.

${ }^{60}$ Münchau W., „Gaps in the eurozone 'football league'“, The Financial Times, 20100321.

${ }^{61}$ Berglof E., Annenkov A., "Baltic lessons for Europe's future economic governance", Europe's World, No. 12,2011 , p. $70-75$.

${ }^{62}$ Münchau W., „Gaps in the eurozone 'football league’“, The Financial Times, 20100321.
} 
truputị veda ES link federacinės valstybės bruožų. Tik nacionaliniais interesais pagrịsta ekonominé politika nèra naudinga žmonių gerovei. „Europos valstybės yra per mažos, kad vienos galètų savo gyventojams suteikti gerovę“, kaip teigè Europos integracijos idèjos autorius Jeanas Monnet’as ${ }^{63}$.

Tommaso Padoa-Schioppa grupé teigia, kad EPS dabartiniu savo pavidalu yra neužbaigta - euro funkcionavimui reikia fiskalinio federalizmo, bet tik tokia apimtimi, kiek tai yra neišvengiama, tačiau kartu ir kiek įmanoma mažiau. Krizè parodè, kad EPS negali ilgiau funkcionuoti senuoju hierarchiniu režimu. Jau ne atskirų šalių narių, o ES kaip visumos lygmuo turi būti pripažintas esmine ekonominès politikos erdve. Bendri veiksmai reikštų pripažinimą, kad suma yra svarbiau nei kiekviena atskira dalis. ES lygmeniu sunku rasti pavyzdžių, kai tikrai būtų imtasi bendrų ekonominių veiksmų (išimtimi laikytina tik pinigų politika ${ }^{64}$.

Kad tokia EPS struktūra yra klaida, buvo pabrèžta dar 1989 m. Delors’o ataskaitoje: „ekonominè sąjunga ir pinigų sajunga sudaro dvi integralias visumos dalis ir todèl turètų būti kuriamos paraleliai“" ${ }^{65}$. Mario Monti taip pat siūlo matyti visą ES bendrąją rinką, o ne tik euro zoną. Daugejjant integracijos priešininkų, bendrajai rinkai reikia greitesnių sprendimų, holistinio matymo. Esmė yra ne kiek įvairiausių institucijų turès ES, o ar bus žiūrima ị jas vienu metu kaip ì susijusią visumą ${ }^{66}$.

Mažų ekonomikų šalys dažnai suabejoja, ar joms ekonominiu ir socialiniu požiūriu naudingi susitarimai su griežtesniais reikalavimais. Pagrindą tam duoda dvigubi standartai. Juk kol dabartinès didžiųjų ekonomikų šalys tik kūre EPS, jos pačios nesilaikè taisyklių, kurių šiandien reikalauja iš mažųų šalių. Vadinasi, jos siekè taisyklių kūrimo, o ne taisyklių perèmimo galių? Internacionalizacijos procesas ateityje mažųjų ir didžiųjų šalių dialogo pobūdị gali pakeisti iš esmès: mažosios šalys gali iš stebètojų virsti veikejomis ir susitarimų pagrindu igyti galios apginti savo interesus ${ }^{67}$.

Tommaso Padoa-Schioppa grupé mano, kad suverenumo reikia atsisa-

\footnotetext{
${ }^{63}$ Monnet J., ,Jean Monnet's thoughts on the future (5 August 1943)“, Archives Jean Monnet, Fondation Jean Monnet pour l'Europe, Lausanne, Fonds AME. 33/1/4, translated by the Translation Centre Virtuel de la Connaissance sur l'Europe, Copyright (CVCE), 1943.

${ }^{64}$ „Completing the Euro. A road map towards fiscal union in Europe“, Report of the "Tommaso PadoaSchioppa Group", Notre Europe, June, 2012.

${ }^{65}$ Committee for the Study of Economic and Monetary Union, "Report on economic and monetary union in the European Community”, Brussels, 1989.

${ }^{66}$ „Strategies for a post-crisis world: enhancing European growth“, Keynote speeches at the Brussels Economic Forum 2010, European Commission, Directorate-General for Economic and Financial Affairs, ECFIN Economic Brief Issue No 9, July 2010.

${ }^{67}$ Kaul J., Grunberg J. and Stern M., eds., Global Public Goods: International Cooperation in the 21st century, New York, Oxford University Press, 1999.
} 
kyti tiek, kad galètų funkcionuoti bendroji valiuta: „ES gali pradèti vykdyti griežtesnę ekonominę politiką tik tada, kai politikos dalyviu bus pati ES, o ne valstybių narių susibūrimas. Tai reiškia, kad reikès atsisakyti didelès dalies suverenumo. Remiantis atitinkamais teisètumo šaltiniais, ES lygmuo turètu būti pripažintas kaip pilnateisis, autonominis veikejas ekonominès politikos formavimo srityje“. Būtina pripažinti ES lygmenị nepriklausomu bendrosios ekonominès politikos formavimo lygmeniu, tačiau sprendimai dèl biudžeto ir ekonominès politikos turi būti priimami nacionaliniu lygiu ${ }^{68}$. Be bendrųjų centrinio banko, pinigų politikos, viešųjų finansų ir fiskalinès politikos institucijų bendroji ekonominè erdvè, kaip viešoji gẻrybė yra negalima. Ekonominès sąjungos ir politinès sąjungos dilema - tai įtampos židinys, kuris buvo suprogramuotas nuo pat euro gimimo, bet visuomené to nežinojo dèl informacijos asimetrijos reiškinio ${ }^{69}$.

Vèliau ar anksčiau, siekdama išlikti vykstant ekonomikos globalizacijai, ES bus priversta keistis ir pripažinti hierarchinius rinkos ir politinės valdžios santykių pokyčius. Internacionalizacija daro ịtaką reguliariam ekonominès raidos etapų atsiverimui ir vèlesni integruotą stabilizavimąsi ir užsidarymą, bet jau aukštesniu hierarchiniu lygiu ir platesnejje institucinejje sistemoje $^{70}$. Dar Delorso komitetas mané, kad ateityje, sukūrus bendrosios valiutos zoną, reikès ir politinès sąjungos ${ }^{71}$. ES privalo gebèti veikti planetos mastu ir siekti politinio koordinatoriaus vaidmens pasaulio hierarchinio laiptelio lygiu ${ }^{72}$.

\section{Vietoj išvadų}

Lietuvos, kaip mažos valstybès, ekonominè strategija remiasi ekonominio saugumo užtikrinimo siekiu. Todèl Lietuvos valstybei tolesnè integruotos Europos ekonomikos raida turi lemiamą reikšmę.

Krizė Lietuvos ekonomiką ištiko dèl tų pačių priežasčių ir tais pačiais

\footnotetext{
${ }^{68}$ „Completing the Euro. A road map towards fiscal union in Europe“, Report of the "Tommaso PadoaSchioppa Group”, Notre Europe, June, 2012.

${ }^{69}$ „Strategies for a post-crisis world: enhancing European growth“, Keynote speeches at the Brussels Economic Forum 2010, European Commission, Directorate-General for Economic and Financial Affairs, ECFIN Economic Brief Issue No 9, July 2010.

${ }^{70}$ Jeffries S., „A rare interview with Jürgen Habermas“, The Financial Times, 20100430.

${ }^{71}$ O’Sullivan J., „Holding Together“, The Economist, 200906 11, http://www.economist.com/specialreports/displaystory.cfm?story_id=13767371.

${ }^{72}$ Jeffries S., „A rare interview with Jürgen Habermas“, The Financial Times, 20100430.
} 
būdais kaip visoje Europoje, bet krizès jèga Lietuvoje (visose Baltijos šalyse) buvo nepalyginamai didesnè nei kitur - tai ir yra geriausias Lietuvos ekonomikos santykinio nesavarankiškumo (išorès atžvilgiu) įrodymas. Dèl to nesavarankiškumo išorès jẻgos pakèle šalies ūkị i aukštesnị (nei jam įmanoma) lygì, o krizès metu bloškè nuo to kalno giliau nei būtų nuoseklesnès plètros atveju.

Todèl ekonominị stabilumą maža šalis gali užsitikrinti tik jungdamasi $\mathfrak{i}$ ekonominès integracijos procesą, kuris tenkina ne tik ekonominio racionalumo ir saugumo poreikius, bet ir atitinka politinių sajungų ir kultūrinès afiliacijos kriterijus ir interesus. Šiuo metu ekonominè integracija Europoje vyksta kaip ES Ekonominès ir pinigų sajungos (EPS) formavimo (plètros) ir konsolidavimo procesas.

EPS kūrimo procese nuo principo „viena tauta (valstybè) - viena valiuta“ pereinama prie principo „viena rinka - viena valiuta“. Kadangi ekonominè integracija Europoje vyksta nepalyginamai sparčiau nei politinè, viena bendroji ES rinka egzistuoja kartu su 27 suvereniomis valstybėmis. Būtent tai padare pinigų sąjungos formavimą daugiaetapiu procesu, o jos funkcionavimą - sudètingą ir rizikingą.

Nèra abejonių, kad ekonominė politika euro erdveje turi būti konsoliduota ir suderinta tiek, kiek to reikia bendrosios pinigu politikos sèkmei. Pinigų sąjunga turi būti papildyta tam tikra fiskaline sąjunga, kuri, netenka abejoti, rutuliosis ị vis glaudesnę ekonominę sąjungą.

Dèl galimo ekonominès sąungos formavimo neišvengiamai turètų keistis ir kai kurios valstybès suverenumo dimensijos. Valstybių išorès ekonominiai santykiai vis labiau organizuojami institucionalizuotais dvišaliais ir daugiašaliais susitarimais, kiekvienu atveju valstybėms atsisakant dalies individualių galimybiu, ir ịsigyjant galimybes (bei įsipareigojimus) spręsti reikalus drauge su kitomis valstybėmis. Akivaizdu, kad ekonomikos sferoje valstybès suverenumas transformuojasi.

Ekonominès integracijos procese valiutų kursų svyravimo kliuvinys anksčiau ar vèliau turi būti pašalinamas radikaliausiu būdu - nacionalinių valiutų pakeitimu bendraja valiuta, taigi - ir bendra pinigų politika. Euro zona gali keisti savo geografinę konfigūraciją, tačiau negali išnykti. Todèl būti Europos Sąjungoje ir nebūti Ekonomineje ir pinigų sąungoje reiškia palaipsniui imti atsilikti integruojantis ị Europą - ekonominèje, taip pat truputị pakurstyti ir politinio ostrakizmo grèsmę. Tai prieštarautų Lietuvos, mažosios valstybès, interesams.

Ekonominè integracija (jei ir kol ji vyksta) neišvengiamai reikalauja ir 
politinès integracijos. Tačiau politinè integracija yra kur kas sudètingesnis ir lètesnis procesas. Jei išorinès jegos nesutrukdys ekonominio (racionalaus) pasaulio integracijos eigos, laipsniškas politinès sąjungos formavimasis Europoje liks tiek pat neišvengiamas, kaip ir dabartinis skatinimas kurti ES šalių politinę sąjungą yra per ankstyvas.

2013 m. vasaris 